Jurnal Media Pertanian Vol. 2 No. 1 Tahun 2017 Hal. 37 - 46

Media Komunikasi Hasil Penelitian dan Review Literatur Bidang Ilmu Agronomi ISSN $2503-1279$

\title{
KARAKTERISTIK FISIK DAN MUTU BUAH KELAPA DALAM (Cocos nucifera L) DI LAHAN PASANG SURUT DAN LAHAN GAMBUT DI KABUPATEN TANJUNG JABUNG BARAT
}

\author{
Rudi Hartawan $^{1 *}$, Nasamsir ${ }^{1}$ dan Abdul Gafur ${ }^{2}$ \\ ${ }^{1}$ Program Studi Agroteknologi, Fakultas Pertanian Universitas Batanghari \\ J1. Slamet Riyadi, Broni Jambi. 36122. Telp. +62074160103 \\ ${ }^{2}$ Alumni Program Studi Agroteknologi, Fakultas Pertanian Universitas Batanghari \\ Jl. Slamet Riyadi, Broni Jambi. 36122. Telp. +62074160103 \\ "email korespondensi: rudi2810@yahoo.com
}

\begin{abstract}
Higher coconut in productivity when cultivated on peat land compared to ups and downs. This research aims to know the physical characteristics and the quality of the fruit of the coconut in a better land differences i.e. tidal land and peat. This research has been carried out in August until September 2016 in the village of Pulau Pinang subdistrict of Tanjung Jabung Regency Right Betara West to site tidal land and the village of Bram Itam Kingdom subdistrict of Tanjung Jabung Regency Itam Bram West location for peat. Analysis of the data obtained from this research is a descriptive statistical analysis method in the form of inference method using the tabulate and test-t paired. Sampling for both villages is conducted at three locations with a distance of 500 metres north of observation which has been previously determined point coordinates using GPS. Each location taken 5 sample with circumference of observed variables fruit, fruit fiber thickness, the thickness of the shell, the thickness of the meat, the weight of the fruit intact, heavy fruit without husk oil yield, moisture content. Every standard of treatment is repeated 3 times, so there are 15 units of the sample in each village, so the total number of samples of coconuts in the two villages as many as 30 units of coconuts. Results of the study concluded that the physical characteristics and the quality of the fruit of the coconut palm plant In dilahan better than peat moss plant coconut in dilahan ups and downs.
\end{abstract}

Keywords: physical characteristics of coconut in, tidal land, peat.

\begin{abstract}
Abstrak
Produktivitas Kelapa Dalam lebih tinggi bila dibudidayakan pada lahan gambut dibandingkan lahan pasang surut. Penelitian ini bertujuan untuk mengetahui karakteristik fisik dan mutu buah Kelapa Dalam yang lebih baik dengan perbedaan lahan yaitu lahan pasang surut dan lahan gambut. Penelitian ini telah dilaksanakan pada bulan Agustus sampai September 2016 di Desa Pulau Pinang Kecamatan Betara Kanan Kabupaten Tanjung Jabung Barat untuk lokasi lahan pasang surut dan Desa Bram Itam Raya Kecamatan Bram Itam Kabupaten Tanjung Jabung Barat untuk lokasi lahan gambut. Analisis data yang diperoleh dari penelitian ini adalah analisis statistika dengan metode deskriptif dalam bentuk tabulasi dan metode inferensi menggunakan uji-t berpasangan. Pengambilan sampel untuk kedua desa dilakukan pada tiga lokasi dengan jarak pengamatan 500 meter arah utara yang sebelumnya telah ditentukan titik koordinat menggunakan GPS. Setiap lokasi diambil 5 sampel dengan peubah yang diamati lingkar buah, ketebalan sabut buah, ketebalan tempurung, ketebalan daging buah, berat buah utuh, berat buah tanpa sabut, rendemen minyak, kadar air. Setiap taraf perlakuan diulang 3 kali, sehingga terdapat 15 unit sampel di setiap desa, jadi jumlah keseluruhan sampel buah kelapa di kedua desa sebanyak 30 unit buah kelapa. Hasil penelitian menyimpulkan bahwa karakteristik fisik dan mutu buah tanaman Kelapa Dalam dilahan gambut lebih baik dibandingkan tanaman Kelapa Dalam dilahan pasang surut.

Kata kunci: karakteristik fisik Kelapa Dalam, lahan pasang surut, lahan gambut.
\end{abstract}


Jurnal Media Pertanian Vol. 2 No. 1 Tahun 2017 Hal. 37 - 46

Media Komunikasi Hasil Penelitian dan Review Literatur Bidang Ilmu Agronomi ISSN $2503-1279$

\section{PENDAHULUAN}

Kelapa Dalam (Cocos nucifera L) merupakan salah satu komoditas perkebunan yang bernilai ekonomis karena memiliki berbagai manfaat. Tanaman Kelapa Dalam banyak dibudidayakan secara luas oleh masyarakat, baik secara monokultur maupun dikombinasikan dengan tanaman padi. Kelapa Dalam bermanfaat untuk meningkatkan taraf hidup masyarakat, karena hampir seluruh bagian tanaman dapat dimanfaatkan mulai dari daging buah, sabut, tempurung, air kelapa, batang, lidi, bahkan akarnya juga bernilai ekonomis (Bustami, Mildaerizanti dan Jumakir 2008).

Provinsi Jambi merupakan sentra Kelapa Dalam di Indonesia. Berikut data luas lahan dan produksi Kelapa Dalam di Provinsi Jambi yang dirinci pada beberapa kabupaten.

Tabel 1. Luas tanam, produksi dan produktivitas Kelapa Dalam berdasarkan kabupaten/kota di Provinsi Jambi tahun 2013 dan 2014

\begin{tabular}{|c|c|c|c|c|c|c|c|}
\hline \multirow[b]{2}{*}{ No. } & \multirow[b]{2}{*}{$\begin{array}{c}\text { Kabupaten/ } \\
\text { Kota }\end{array}$} & \multicolumn{3}{|c|}{ Tahun 2013} & \multicolumn{3}{|c|}{ Tahun 2014} \\
\hline & & $\begin{array}{c}\text { Luas } \\
\text { Tanam } \\
\text { (ha) }\end{array}$ & $\begin{array}{l}\text { Produksi } \\
\quad \text { (ton) }\end{array}$ & $\begin{array}{l}\text { Produk- } \\
\text { tivitas } \\
\left(\text { ton } \mathrm{ha}^{-1}\right)\end{array}$ & $\begin{array}{c}\text { Luas } \\
\text { Tanam } \\
\text { (ha) }\end{array}$ & $\begin{array}{l}\text { Produksi } \\
\quad \text { (ton) }\end{array}$ & $\begin{array}{l}\text { Produk- } \\
\text { tivitas } \\
\left(\text { ton } \mathrm{ha}^{-1}\right)\end{array}$ \\
\hline 1. & Kerinci & 77 & 19 & 0.25 & 77 & 19 & 0.25 \\
\hline 2. & Merangin & 1.839 & 908 & 0.49 & 1.407 & 886 & 0.63 \\
\hline 3. & Sarolangun & 570 & 304 & 0.53 & 583 & 310 & 0.53 \\
\hline 4. & Batanghari & 512 & 395 & 0.77 & 440 & 354 & 0.80 \\
\hline 5. & Ma. Jambi & 902 & 587 & 0.65 & 902 & 597 & 0.66 \\
\hline 6. & Tanjabtim & 58.620 & 50.254 & 0.91 & 58.650 & 53.382 & 0.99 \\
\hline 7. & Tanjabbar & 53.724 & 53.382 & 0.94 & 53.724 & 53.013 & 0.98 \\
\hline 8. & Tebo & 1.007 & 541 & 0.54 & 960 & 526 & 0.55 \\
\hline 9. & Bungo & 699 & 476 & 0.68 & 719 & 476 & 0.66 \\
\hline 10. & Kota Jambi & 0 & 0 & 0.00 & 0 & 0 & 0.00 \\
\hline 11. & $\begin{array}{l}\text { Kota Sungai } \\
\text { Penuh }\end{array}$ & 4 & 3 & 0.75 & 4 & 3 & 0.75 \\
\hline \multicolumn{2}{|c|}{ Total } & 116.948 & 106.869 & & 117.466 & 107.566 & \\
\hline \multicolumn{2}{|c|}{ Rumah Tangga Tani } & 94.574 & & & 94.270 & & \\
\hline
\end{tabular}

Sumber : Jambi Dalam Angka (2014 dan 2015)

Tabel di atas menunjukkan bahwa Kabupaten Tanjung Jabung Barat dengan luas areal Kelapa Dalam mencapai 53.724 hektar dengan jumlah total produksi 53.013 ton (BPS Tanjung Jabung Barat, 2015). Pada tahun 2014, komposisi tanaman Kelapa Dalam di Kabupaten Tanjung Jabung Barat disajikan pada Tabel 2 berikut.

Tabel 2. Luas areal dan produksi tanaman Kelapa Dalam menurut kecamatan Kabupaten Tanjung Jabung Barat Tahun 2014

\begin{tabular}{|l|l|c|c|}
\hline No. & \multicolumn{1}{|c|}{ Kecamatan } & Luas $(\mathrm{Ha})$ & Produksi (Ton) \\
\hline 1. & Tungkal Ulu & 11 & 10 \\
\hline 2. & Merlung & 0 & 0 \\
\hline 3. & Batang Asam & 22 & 10 \\
\hline 4. & Tebing Tinggi & 0 & 0 \\
\hline 5. & Renah Mendaluh & 12 & 4 \\
\hline 6. & Muara Papalik & 12 & 5 \\
\hline 7. & Pengabuan & 11.204 & 9.076 \\
\hline 8. & Senyerang & 10.993 & 10.153 \\
\hline 9. & Tungkal Ilir & 6.068 & 8.143 \\
\hline 10. & Bram Itam & 5.690 & 6.543 \\
\hline 11. & Seberang Kota & 6.127 & 6.418 \\
\hline
\end{tabular}


Jurnal Media Pertanian Vol. 2 No. 1 Tahun 2017 Hal. 37 - 46

Media Komunikasi Hasil Penelitian dan Review Literatur Bidang Ilmu Agronomi ISSN $2503-1279$

\begin{tabular}{|l|l|c|c|}
\hline \hline 12. & Betara & 4.361 & 1.833 \\
\hline 13. & Kuala Betara & 9.224 & 10.818 \\
\hline \multicolumn{2}{|c|}{ Total } & 53.724 & 53.013 \\
\hline
\end{tabular}

Sumber : Badan Pusat Statistik Kabupaten Tanjung Jabung Barat (2015)

Tabel 2 diatas menunjukan adanya ketidakseimbangan antara produksi dengan luas areal kelapa, seperti di Kecamatan Betara dengan luas areal 4.361 hektar hanya menghasilkan produksi 1.833 ton, sedangkan di Kecamatan Bram Itam dengan luas areal 5.690 hektar mampu menghasilkan produksi sebesar 6.543 ton. Di Kecamatan Betara, Kelapa Dalam dibudidayakan di lahan gambut dengan kedalaman $50-60 \mathrm{~cm}$ dan masih sangat kuat dipengaruhi oleh pasang surut air laut. Di Kecamatan Bram Itam, Kelapa Dalam dibudidayakan di lahan gambut dengan kedalaman $20-40 \mathrm{~cm}$ dan tidak dipengaruhi langsung oleh pasang dan surut air laut. Perbedaan kondisi lahan tersebut diduga yang mempengaruhi produktivitas kelapa.

Perbedaan sifat fisik dan kimia tanah menyebabkan tidak semua lahan gambut dapat digunakan sebagai lahan pertanian. Tanah gambut memiliki sifat khusus yang tidak dimiliki oleh jenis tanah yang lainnya, yaitu kemampuan menahan air yang sangat tinggi sebesar $450-3.000 \%$ dari berat kering tanah untuk gambut hemik dan fibrik. Oleh sebab itu gambut merupakan tempat penampungan air yang efisien dan dapat mengatur aliran permukaan dan air tanah (Soewandita, 2008).

Kesesuaian lahan untuk pertanaman Kelapa Dalam pada dasarnya didasarkan atas horizon dimana tanaman akan ditanam, sifat fisika tanah, dan kemampuan tanah dalam menahan air. Kebaradaan air di dalam tanah merupakan dasar pengkelasan kesesuaian lahan untuk tanaman Kelapa Dalam karena berpengaruh terhadap penggunaan air khususnya ketika masa kekeringan. Air tanah juga berpengaruh terhadap luas daun tanaman kelapa dan kapasitas penyimpanan air di batang yang keduanya berpengaruh terhadap laju transpirasi tanaman selanjutnya akan mempengaruhi karakteristik mutu buah (Hidayati, 2013).

Mutu buah kelapa dipengaruhi oleh karakter fisiko-kimia komponen buah kelapa, yang secara langsung dipengaruhi oleh jenis dan umur buah kelapa; secara tidak langsung oleh lingkungan tumbuh dan pemeliharaan (Abdurachman dan Mulyani, 2003). Lingkungan tumbuh yang sesuai dan pemeliharaan yang baik akan menghasilkan bahan baku bermutu untuk diolah lebih lanjut (Rindengan, Novarianto, dan Mahmud 1996; Tenda, Lengkey dan Kumaunang, 1997).

Berdasarkan uraian diatas perlu kiranya dilakukan pengecekan di lapangan (data empiris) karakteristik fisik dan mutu buah Kelapa Dalam yang dibudidayakan di lahan pasang surut dan lahan gambut khususnya di Kabupaten Tanjung Jabung Barat Provinsi Jambi.

\section{METODE PENELITIAN}

Pengambilan sampel penelitian dilaksanakan pada dua lahan yang berbeda, yaitu lahan pasang surut dan lahan gambut. Lahan pasang surut berlokasi di Desa Pulau Pinang Kecamatan Betara Kanan Kabupaten Tanjung Jabung Barat dengan kedalaman gambut $50-60 \mathrm{~cm}$. Lahan gambut berlokasi Desa Bram Itam raya Kecamatan Bram Itam Kabupaten Tanjung Jabung Barat dengan kedalaman gambut $20-40 \mathrm{~cm}$. Penelitian dilakukan pada bulan Agustus sampai September 2016.

Bahan yang digunakan dalam penelitian ini adalah tanaman Kelapa Varietas Dalam dengan umur 15 tahun yang ditanam pada lahan pasang surut dan lahan gambut. 
Jurnal Media Pertanian Vol. 2 No. 1 Tahun 2017 Hal. 37 - 46

Media Komunikasi Hasil Penelitian dan Review Literatur Bidang Ilmu Agronomi ISSN $2503-1279$

Peralatan yang digunakan dalam penelitian ini dikelompokkan menjadi tiga yaitu peralatan untuk penentuan karakteristik buah, peralatan untuk pembuatan minyak dan peralatan untuk analisis kimia. Peralatan untuk penentuan karakteristik buah meliputi meteran, timbangan duduk, timbangan digital (Digital Weight). Peralatan pendukung lainnya adalah GPS (Global Position System) dan golok atau parang untuk mengupas buah kelapa. Peralatan pembuatan minyak antara lain adalah parutan kelapa, saringan santan, wadah plastik, selang plastik kecil, kompor, dan wajan (penggorengan). Peralatan analisis kimianya antara lain pipet volume, gelas ukur, dan oven.

Penelitian dilakukan dengan metode survey di kebun-kebun masyarakat yaitu kebun kelapa dengan kondisi lahan gambut yang tidak dipengaruhi oleh pasang surut dan lahan gambut pasang surut. Sampel buah diambil dari tanaman milik rakyat yang berumur 15 tahun.

Metode pengambilan sampel mengunakan metode SRS (simple random sampling). Jika jumlah populasi tanaman lebih dari 100 maka tanaman sampel sebanyak 15\% sedangkan bila populasi tanaman kurang dari 100 maka tanaman sampel sebanyak 50\% (Tasri, 2007). Pengambilan sampel untuk kedua desa dilakukan pada tiga lokasi dengan jarak pengamatan $500 \mathrm{~m}$ arah Utara. Tanaman sampel dipilih secara sengaja, yang sebelumnya telah ditentukan titik koordinat dan ketinggian tempat dengan mengunakan GPS. Titik pengambilan sampel dan $\mathrm{pH}$ tanah disajikan pada Tabel berikut:

Tabel 3. Koordinat dan pH tanah lokasi sampel

\begin{tabular}{|c|c|c|c|}
\hline No. & Ekologi Lahan dan Nama Desa & Koordinat Titik Sampel & pH Tanah \\
\hline \multirow[t]{3}{*}{1.} & \multirow[t]{3}{*}{$\begin{array}{l}\text { Pasang Surut, Desa Pulau Pinang, } \\
\text { Kecamatan Betara Kanan }\end{array}$} & $\begin{array}{l}\text { Sampel } 1 \\
\text { S. } 00^{\circ} 5^{\prime} 03,41^{\prime}, \\
\text { E. } 103^{\circ} 28,35,077^{\prime}\end{array}$ & 4,8 \\
\hline & & $\begin{array}{l}\text { Sampel } 2 \\
\text { S. } 00^{\circ} 50^{\prime} 52,37^{\prime \prime} \\
\text { E. } 103^{\circ} 28^{\prime} 37,807^{\prime \prime}\end{array}$ & 5,4 \\
\hline & & $\begin{array}{l}\text { Sampel } 3 \\
\text { S. } 00^{\circ} 50^{\prime} 45,37^{\prime \prime} \\
\text { E. } 103^{\circ} 28^{\prime} 37,597^{\prime}\end{array}$ & 4,6 \\
\hline \multirow[t]{3}{*}{2.} & \multirow[t]{3}{*}{$\begin{array}{l}\text { Lahan Gambut, Desa Bram Itam } \\
\text { Raya, Kecamatan Bram Itam }\end{array}$} & $\begin{array}{l}\text { Sampel 1 } \\
\text { S. } 00^{\circ} 53^{\prime} 54,13 \text { ' } \\
\text { E. } 103^{\circ} 22^{\prime} 37,479^{\prime}\end{array}$ & 5 \\
\hline & & $\begin{array}{l}\text { Sampel } 2 \\
\text { S. } 00^{\circ} 53^{\prime} 37,70^{\prime \prime} \\
\text { E. } 103^{\circ} 22^{\prime} 38,337^{\prime}\end{array}$ & 5 \\
\hline & & $\begin{array}{l}\text { Sampel } 3 \\
\text { S. } 00^{\circ} 53^{\prime} 22,46 ” \\
\text { E. } 103^{\circ} 22^{\prime} 33,487^{\prime \prime}\end{array}$ & 4,6 \\
\hline
\end{tabular}

Pada setiap lokasi ditentukan 5 tanaman yang akan dijadikan tanaman sampel. Masing-masing tanaman sampel diambil satu tandan buah yang sudah matang atau tua, selanjutnya buah tersebut di jadikan sebagai sampel buah.

Peubah fisik buah kelapa yang diamati adalah 1) lingkar buah, ditentukan dengan cara mengukut lingkar buah yang sudah matang dengan mengunakan alat ukur 
Jurnal Media Pertanian Vol. 2 No. 1 Tahun 2017 Hal. 37 - 46

Media Komunikasi Hasil Penelitian dan Review Literatur Bidang Ilmu Agronomi ISSN $2503-1279$

berupa meteran; 2) ketebalan sabut buah, diukur mulai dari kulit luar hingga tempurung bagian luar daging buah dengan menggunakan penggaris; 3) ketebalan tempurung, diukur mulai dari bagian luar tempurung hingga bagian dalam tempurung tempat melekatnya daging buah. Alat yang digunakan adalah penggaris; 4) ketebalan daging buah, diukur dengan menggunakan penggaris mulai dari bagian buah yang berwarna kecoklatan yaitu pangkal tempat melekatnya daging buah dengan tempurung hingga bagian dalam daging buah yang berwarna putih; 5) berat buah, dilakukan dengan cara memetik buah yang sudah matang kemudian buah dibersihkan dari tangkai buah dan kelopak buah kemudian buah ditimbang mengunakan timbangan digital yang sudah distandarkan dengan berat uji; 6) berat buah tanpa sabut, dilakukan dengan cara mengelupas sabut buah kelapa dari tempurung buah kelapa hingga bersih selanjutnya buah di timbang dengan mengunakan timbangan.

Peubah mutu yang diamati adalah 1) rendamen minyak, penentuan rendemen minyak dilakukan dengan metode gravimetri (v/v) (Soeka, Sulistyo dan Naiola, 2008) dengan rumus:

$$
\text { Re } n \text { demen }=\frac{\text { Volume } \min \text { yak terbentuk }(\mathrm{ml})}{\text { Volume krim santan }(\mathrm{ml})} \times 100 \% .
$$

Proses fisika (pemanasan) digunakan untuk mengekstrak minyak dari krim santan. Cara yang digunakan sebagai berikut: Daging buah kelapa diparut lalu peras diambil santannya, santan murni diambil dengan takaran 1 liter, santan yang diperoleh di masukkan kedalam wadah penggorengan kemudian dididihkan sampai terbentuk lapisan minyak di permukaan cairan, lapisan minyak yang terdapat di permukaan ini diambil menggunakan sendok sampai semua minyak terambil dan bagian minyak ini dipanaskan sampai matang yang membutuhkan waktu sekitar 130 - 133 menit; 2) kadar air, metode yang digunakan adalah Thermogravimetri (Suastuti, 2009), yang prinsipnya adalah menguapkan air yang ada dalam bahan dengan jalan pemanasan, kemudian menimbang bahan sampai berat konstan: 1) wadah tahan panas dioven pada suhu $80^{\circ} \mathrm{C}$ selama 45 menit kemudian didinginkan. Setelah dingin wadah ditimbang sehingga diperoleh berat wadah kosong; 2) minyak kelapa kemudian dioven pada suhu $80^{\circ} \mathrm{C}$ selama 45 menit; 3) wadah yang berisi sampel didinginkan kemudian ditimbang sampai berat konstan. Rumus yang digunakan adalah:

$$
\text { Kadar air }(\%)=\frac{\text { Berat awal }- \text { Berat akhir }}{\text { Berat awal }} \times 100 \%
$$

Data yang diperoleh dianalisis statistika dengan metode deskriptif dalam bentuk tabulasi dan metode inferensi menggunakan uji - $t$ berpasangan dengan sampel kurang dari 30 dengan rumus sebagai berikut $: t_{\text {hitung }}=\frac{\overline{x_{1}}-\overline{x_{2}}}{\sqrt{\left\{\frac{\left(n_{1}-1\right) s_{1}^{2}+\left(n_{2}-1\right) s_{2}^{2}}{n_{1}+n_{2}-2}\right\}\left\{\frac{1}{n_{1}}+\frac{1}{n_{2}}\right\}}}$

\section{Keterangan:}

$t_{\text {hit }}=$ Nilai - nilai $t$ hasil pehitungan, $x_{1}=$ Nilai - nilai data lahan gambut, $x_{2}=$ Nilai nilai data lahan pasang surut, $\mathrm{n}_{1}=$ Sample lahan gambut, $\mathrm{n}_{2}=$ Sample lahan pasang surut, $\mathrm{S}_{1}{ }^{2}=$ Simpangan data lahan gambut dan $\mathrm{S}_{2}{ }^{2}=$ Simpangan data lahan pasang surut. 
Jurnal Media Pertanian Vol. 2 No. 1 Tahun 2017 Hal. 37 - 46

Media Komunikasi Hasil Penelitian dan Review Literatur Bidang Ilmu Agronomi ISSN $2503-1279$

\section{HASIL DAN PEMBAHASAN}

\section{Karakteristik Fisik Buah}

Berdasarkan hasil pengamatan dan pengukuran beberapa karakteristik fisik buah Kelapa Dalam yang ditanam di dua lokasi berbeda yaitu lahan pasang surut dan lahan gambut, diperoleh data sebagai berikut:

Tabel 4. Rerata nilai peubah kualitas fisik buah Kelapa Dalam pada ekologi lahan pasang surut dan gambut

\begin{tabular}{|l|l|l|c|c|}
\hline No. & \multicolumn{1}{|c|}{ Peubah, Satuan } & Ekologi Lahan & Rerata Nilai & Notasi \\
\hline \multirow{2}{*}{1.} & \multirow{2}{*}{ Lingkar Buah $(\mathrm{cm})$} & Pasang Surut & 54,66 & $\mathrm{a}$ \\
\cline { 3 - 5 } & & Gambut & 61,60 & $\mathrm{~b}$ \\
\hline \multirow{2}{*}{3.} & \multirow{2}{*}{ Tebal Sabut $(\mathrm{cm})$} & Pasang Surut & 2,09 & $\mathrm{a}$ \\
\cline { 3 - 5 } & & Gambut & 3,13 & $\mathrm{~b}$ \\
\hline \multirow{2}{*}{4.} & \multirow{2}{*}{ Ketebalan Daging Buah $(\mathrm{mm})$} & Pasang Surut & 4,33 & $\mathrm{a}$ \\
\cline { 3 - 5 } & & Gambut & 3,53 & $\mathrm{a}$ \\
\hline \multirow{2}{*}{5.} & Berat Buah Utuh $(\mathrm{kg})$ & Pasang Surut & 9,66 & $\mathrm{a}$ \\
\cline { 3 - 5 } & & Gambut & 11,33 & $\mathrm{~b}$ \\
\hline 6. & Berat Buah tanpa Sabut $(\mathrm{g})$ & Gasang Surut & 1,47 & $\mathrm{a}$ \\
\cline { 3 - 5 } & & Gambut & 1,70 & $\mathrm{a}$ \\
\cline { 3 - 5 } & & Gambut Surut & 760,00 & $\mathrm{a}$ \\
\hline
\end{tabular}

Keterangan: Angka-angka setiap peubah yang diikuti oleh huruf kecil yang sama berbeda tidak nyata berdasarkan uji t berpasangan dengan ketelitian 95\%

Berdasarkan hasil uji-t dari beberapa parameter fisik dan mutu buah kelapa yang ditanam di lahan pasang surut dan lahan gambut di Kabupaten Tanjung Jabung Barat menunjukkan bahwa buah Kelapa Dalam yang ditanam di Desa Bram Itam Raya dalam kecamatan Bram Itam yang merupakan lahan gambut memiliki mutu buah Kelapa yang lebih baik dibanding buah Kelapa Dalam yang ditanam pada lahan pasang surut di Desa Pulau Pinang, Kecamatan Betara Kanan.

Perbedaan karakteristik fisik dan mutu buah kelapa tersebut diduga terkait dengan kondisi lahan yaitu ketebalan gambut. Menurut Najiyati, Lili Muslihat dan Suryadiputra (2005), umumnya ketebalan gambut di Indonesia membentuk kubah gambut (peat dome). Bentuk dari ketebalan gambut tersebut disajikan pada Gambar 1. Lokasi 2

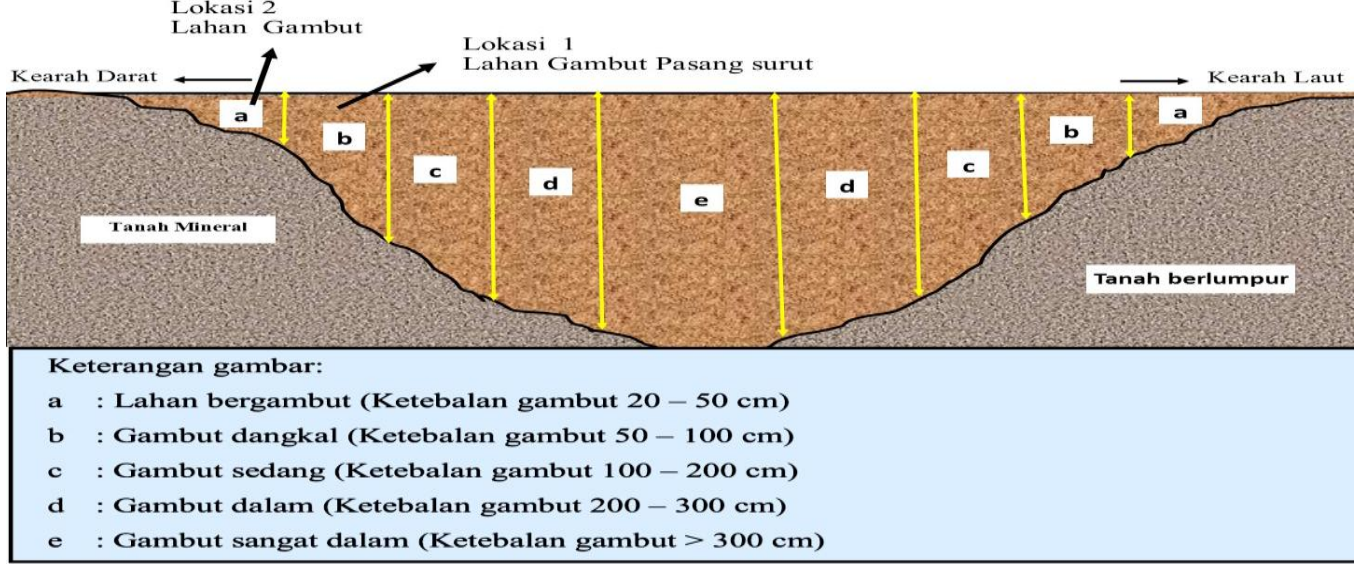

Gambar 1. Kontour ketebalan gambut pada lahan gambut 
Jurnal Media Pertanian Vol. 2 No. 1 Tahun 2017 Hal. 37 - 46

Media Komunikasi Hasil Penelitian dan Review Literatur Bidang Ilmu Agronomi ISSN $2503-1279$

Berdasarkan kedalaman gambut yang disajikan pada Gambar 1, menunjukkan bahwa lokasi 1 yaitu lahan pasang surut termasuk kedalam lahan gambut tipe b dengan kedalaman gambut $50-100 \mathrm{~cm}$. Sedangkan untuk lahan pada lokasi 2 merupakan lahan gambut tipe a dengan kedalaman gambut $20-50 \mathrm{~cm}$.

Lahan yang berada pada lokasi 2 cenderung memiliki unsur hara yang lebih baik dari pada lahan pada lokasi 1. Perbedaan kondisi lahan tersebut berpengaruh terhadap karakteristik fisik dan mutu buah kelapa. Pada lahan yang berada dipinggiran kubah dengan kedalaman gambut $<50 \mathrm{~cm}$ (Lokasi 2 atau lahan gambut) akar tanaman kelapa mampu mengambil unsur hara yang berasal dari tanah mineral dan air tanah, sehingga nutrisi yang cukup menjadikan tanaman kelapa tumbuh dengan baik. Berbeda dengan tanaman kelapa yang berada dilahan pasang surut (lokasi 1), dengan ketebalan gambut $>50 \mathrm{~cm}$ akar tanaman akan sulit untuk memperoleh hara sehingga hal tersebut menyebabkan tanaman kelapa tidak tumbuh secara maksimal yang akhirnya mutu buah kelapa menjadi kurang baik.

Alasan tersebut diatas sesuai dengan pendapat yang dikemukakan oleh Najiyati et al (2005), bahwa pada bagian pinggiran kubah, tumbuhan masih memperoleh pasokan hara dari air tanah dan sungai sehingga ukuran tumbuhan umumnya berdiameter besar. Menuju ke bagian tengah, letak air tanah sudah terlalu dalam sehingga perakaran tumbuhan tidak mampu mencapainya. Akibatnya, tumbuhan hanya memperoleh sumber hara yang semata-mata berasal dari air hujan, sehingga tumbuhan relatif kurus dengan rata-rata berdiameter kecil. Gambut tebal yang terbentuk, umumnya bersifat masam dan miskin hara sehingga memiliki kesuburan alami yang rendah sampai sangat rendah.

Hasil pengamatan peubah ketebalan tempurung dan berat buah utuh menunjukan perbedaan yang tidak nyata, hal ini diduga karena peubah tersebut tidak secara langsung di pengaruhi oleh nutrisi atau peubah tersebut bisa juga di kendalikan secara genetik. Dengan demikian masalah lingkungan tidak di ekpresikan.

Bobot buah Kelapa Dalam dengan sabut tidak berbeda antara yang di tanam di lahan gambut dan lahan pasang surut. Namun demikian jika sabut tersebut dilepas, maka Kelapa Dalam dilahan gambut lebih berat dari pada lahan pasang surut. Sabut Kelapa Dalam dilahan pasang surut lebih tebal dari pada sabut Kelapa Dalam dilahan gambut.

Perbedaan ketebalan sabut ini diduga terkait dengan bentuk adaptasi terhadap kondisi lingkungan. Sabut kelapa dilahan pasang surut cenderung lebih tebal karena bila buah kelapa jatuh akan langsung terkena air, maka sabut yang tebal ini akan melindungi embrio kelapa untuk menghambat proses pembusukan.

\section{Rendemen Minyak}

Hasil kelapa di Tanjung Jabung Barat umumnya dibuat kopra yang produk akhirnya adalah minyak kelapa. Dengan demikian peubah penentu adalah rendemen minyak jadi dapat di katakan bahwa lahan gambut dan lahan pasang surut mempengaruhi mutu buah Kelapa Dalam. Rendemen minyak pada pasang surut sebesar $20,34 \%$ dan lahan gambut sebesar $23 \%$. 
Jurnal Media Pertanian Vol. 2 No. 1 Tahun 2017 Hal. 37 - 46

Media Komunikasi Hasil Penelitian dan Review Literatur Bidang Ilmu Agronomi ISSN $2503-1279$

Tabel 4. Rerata nilai peubah kualitas fisik buah Kelapa Dalam pada ekologi lahan pasang surut dan gambut

\begin{tabular}{|l|l|l|c|c|}
\hline No. & \multicolumn{1}{|c|}{ Peubah, Satuan } & Ekologi Lahan & Rerata Nilai & Notasi \\
\hline \multirow{2}{*}{1.} & Rendemen Minyal (\%) & Pasang Surut & 20,34 & $\mathrm{a}$ \\
\cline { 3 - 5 } & & Gambut & 23,00 & $\mathrm{~b}$ \\
\hline \multirow{2}{*}{2.} & Kadar Air (\%) & Pasang Surut & 0,11 & $\mathrm{a}$ \\
\cline { 3 - 5 } & & Gambut & 0,20 & $\mathrm{~b}$ \\
\hline
\end{tabular}

Keterangan: Angka-angka setiap peubah yang diikuti oleh huruf kecil yang sama berbeda tidak nyata berdasarkan uji t berpasangan dengan ketelitian 95\%

Rendemen minyak dari Kelapa Dalam yang dibudidayakan di lahan gambut lebih tinggi dibandingkan dari lahan pasang surut. Perbedaan ini telah diawali dari beberapa karakter fisik yang telah dikemukakan sebelumnya bahwa kualitas fisik buah lebih bagus bila Kelapa Dalam dibudidayakan di lahan gambut. Karakter fisik yang lebih baik ini dikarenakan tanaman Kelapa Dalam dilahan gambut memiliki kesempatan mendapatkan unsur hara lebih banyak dibandingkan di lahan pasang surut.

Rendemen minyak sebesar $23 \%$ yang didapat dari penelitian ini tergolong rendah dari kandungan potensial yang terdapat dalam kelapa tua yaitu 34\% (Badan Standardisasi Nasional, 2009). Hasil ini tergolong wajar karena proses yang digunakan untuk menghasilkan minyak adalah proses fisika (pemanasan). Rendeman minyak yang tinggi bisa didapat dengan metode fermentasi (35\%) seperti yang dilakukan oleh Sulistyo, Handayani dan Rahayu (2009) dan Widjaja dan Anjarsari (2015).

Kadar air menurut standar mutu minyak kelapa murni SNI 0,1\% sampai 0,5\% dan dari kedua lahan tersebut kadar air rendemen minyak di lahan pasang surut $0,11 \%$, gambut $0,20 \%$ berarti pada lahan pasang surut kadar airnya lebih tinggi di bandingkan dengan lahan gambut. Kondisi ini juga didukung oleh rendemen minyak pada lahan pasang surut lebih rendah dibanding kan dengan lahan gambut.

Warna minyak pada masing-masing lahan memiliki 3 sampel dengan lokasi A (Lahan pasang surut) gradasi yelow orange grade 6, sementara pada lokasi B (Lahan gambut) dengan gradasi orange grade 2 (Gambar 2 dan 3.)

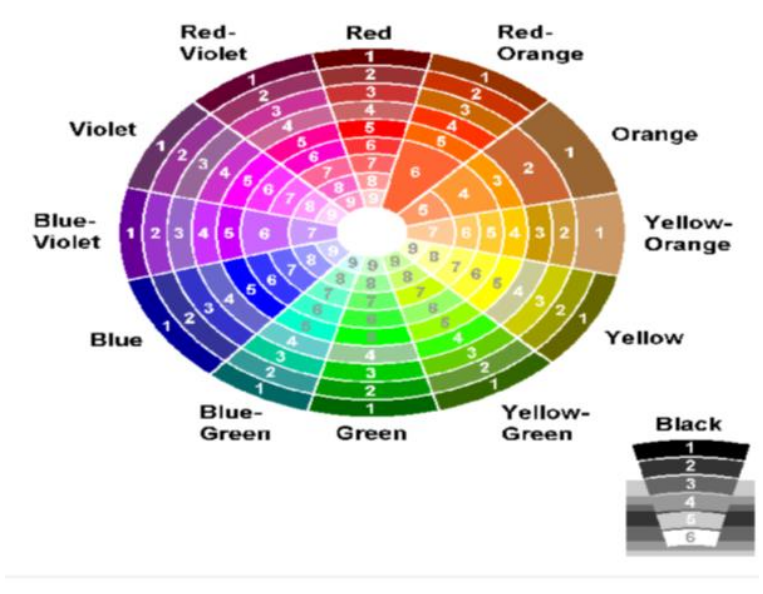

Gambar 2. Gradasi warna

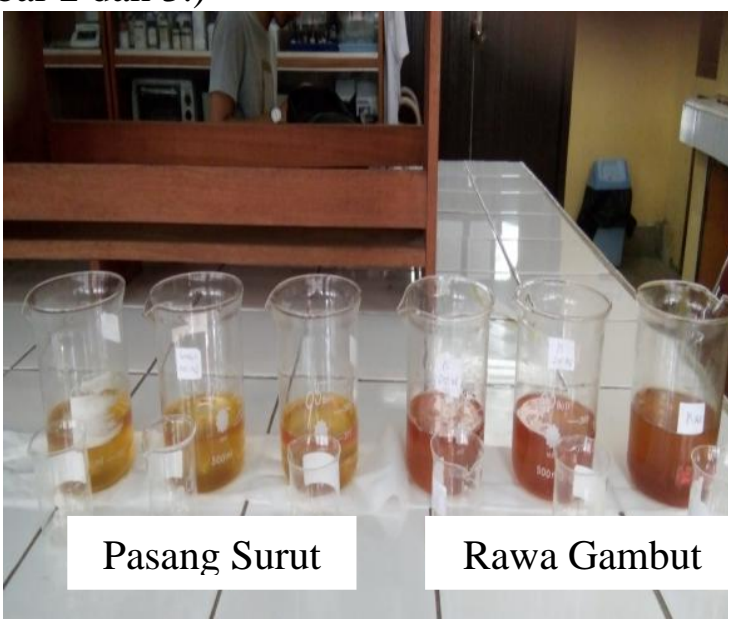

Gambar 3. Gradasi warna minyak hasil penelitian 
Jurnal Media Pertanian Vol. 2 No. 1 Tahun 2017 Hal. 37 - 46

Media Komunikasi Hasil Penelitian dan Review Literatur Bidang Ilmu Agronomi ISSN $2503-1279$

Menurut standar mutu minyak kelapa murni SNI kriteria mutu warna ialah tidak berwarna hingga kuning pucat dari kedua lahan tersebut lokasi A memiliki kriteria SNI warna (bening) dibandingkan dengan lokasi $\mathrm{B}$, hal ini dikarnakan banyaknya unsur hara yang diperoleh dilokasi B sehingga asam lemak bebas semakin tinggi sehingga warna minyak menjadi kecoklatan dan dalam hal ini bisa juga disebab kan oleh proses pembuatan rendemen minyak.

\section{KESIMPULAN}

Berdasarkan hasil penelitian yang diperoleh dapat disimpulkan bahwa Kelapa Dalam yang ditanam pada lahan gambut dan lahan pasang surut menunjukkan perbedaan ukuran lingkar buah, ketebalan sabut, ketebalan daging buah, berat buah tanpa sabut dan mutu buah yaitu rendamen minyak dan kadar air, sedangkan ketebalan tempurung dan berat buah utuh berbeda tidak nyata.

Karakteristik fisik dan mutu buah Kelapa Dalam yang ditanam pada lahan gambut lebih baik dari pada Kelapa Dalam yang ditanam di lahan pasang surut. Pada lahan gambut dengan ketebalan $<50 \mathrm{~cm}$ akar tanaman kelapa dapat memperoleh unsur hara yang lebih baik dari pada kelapa yang ditanam pada lahan pasang surut degan ketebalan gambut $>60 \mathrm{~cm}$.

\section{DAFTAR PUSTAKA}

Abdurachman dan Mulyani. 2003. Kesesuaian lahan tanaman kelapa. (online), http://www.anakagronomy.com/2013/04/analisis-kesesuaian-lahan-untuktanaman.html. Diakses pada tanggal 20 Juli 2016.

Badan Standardisasi Nasional. 1992. Standar Nasional Indonesia (SNI:01-2902-1992), Mutu dan Cara Uji Minyak Kelapa, Jakarta

Badan Pusat Statistik Tanjung Jabung Barat. 2015. Tanjung Jabung Barat Dalam Angka. BPS Tanjung Jabung Barat

Badan Pusat Statistik Jambi. 2015. Jambi Dalam Angka. BPS Jambi

Badan Pusat Statistik Jambi. 2014. Jambi Dalam Angka. BPS Jambi

Bustami., Mildaerizanti dan Jumakir. 2008. Usahatani Kelapa Dalam Di Lahan Pasang Surut Sungai Kepayang Tanjung Jabung Barat. Balai Pengkajian Teknologi Pertanian Jambi.

Hidayati. N, 2013. Kadar Air Pada Minyak Kelapa Hasil Olahan Tradisional Dan Hasil Olahan Dengan Penambahan Buah Nanas Muda. Fakultas Ilmu Kesehatan, Universitas Setia Budi Surakarta.

Najiyati, S., Lili Muslihat dan I Nyoman N. Suryadiputra. 2005. Panduan pengelolaan lahan gambut untuk pertanian berkelanjutan. Proyek Climate Change, Forests and Peatlands in Indonesia. Wetlands International - Indonesia Programme dan Wildlife Habitat Canada. Bogor. Indonesia.

Rindengan, B., A. Lay, H. Novarianto, dan Z. Mahmud. 1996. Pengaruh jenis dan umur buah terhadap sifat fisikokimia daging buah kelapa hibrida dan pemanfaatannya. Jurnal Penelitian Tanaman Industri 1(6): 263-277

Soewandita, H. 2008. Studi Kesuburan Tanah dan Analisis Kesesuaian Lahan untuk Komoditas Tanaman Perkebunan di Kabupaten Bengkalis. Jurnal Sains dan Teknologi Indonesia Vol.10 (2); 128-133 
Jurnal Media Pertanian Vol. 2 No. 1 Tahun 2017 Hal. 37 - 46

Media Komunikasi Hasil Penelitian dan Review Literatur Bidang Ilmu Agronomi ISSN $2503-1279$

Soeka, Y.S., J. Sulistyo Dan E. Naiola. 2008. Analisis Biokimia Minyak Kelapa Hasil Ekstraksi secara Fermentasi. B I O D I V E R S I T A S, Volume 9, Nomor 2 April 2008. Halaman: 91-95

Suastuti. A. D. 2009. Kadar Air Dan Bilangan Asam Dari Minyak Kelapa Yang Dibuat Dengan Cara Tradisional Dan Fermentasi. Jurnal Kimia 3 (2) Juli 2009 : 69-74.

Sulistyo J, R. Handayani, R.D. Rahayu. 2009. Extraction of coconut oil (Cocos nucifera L.) through fermentation system. Journal of Biological Diversity 10: 151-157.

Tasri, E. S. 2007. Metodologi Penelitian Ekonomi Dan Bisnis. Universitas Bung Hatta. Padang.

Widjaja, W.P. dan B. Anjarsari. 2015. Optimasi kondisi fermentasi pada pembuatan minyak kelapa (Cocos nucifera L) dengan menggunakan Saccharomyces cerevisiae. Laporan Penelitian. Univ. Pasundan 